\title{
Effect on Power Quality of the High Power Electric Traction (Double Domain Computer Simulation vs. Site Measurements)
}

\author{
Dr. András Dán, Péter Kiss \\ Department of Electric Power Engineering, Power Systems and Environment Group \\ Budapest University of Technology and Economics \\ Egry József u. 18, H-1111 Budapest (Hungary) \\ Phone number: +0036 1 4633019, fax:+0036 1 4633013, e-mail: dan.andras@,vet.bme.hu, \\ kiss2.peter@phd.vet.bme.hu
}

\begin{abstract}
The paper shows the present results of a long term research work. The authors are working on the modelling of penetration of harmonics caused by the railways.

In a former paper [1] a detailed model of the traction system was discussed in frequency domain. However this paper presents the combination of frequency and time dependent model. This novel method, called double domain method is used to improve the accuracy of the frequency domain simulation. To calculate the sophisticated model of the electric locomotive as a non-linear load a time dependent model must be used. The traction supply system together with the equivalent supply network impedance could be calculated in frequency domain. An iteration algorithm is developed to converting the variables in every iteration step between the time and frequency domain.
\end{abstract}

\section{Keywords}

Power quality, harmonic disturbance, traction supply systems, computer simulation, harmonic filtering

\section{Introduction}

The electric railway is in a competition with other possibilities of transportation. The locomotives became faster and faster and in consequence their power is growing as well. The high power locomotives pollute the supply system with harmonics. In order to ensure the voltage quality of the whole energy system, it is necessary to reduce this pollution.

Strict requirements were established on the voltage quality of the electric supply network in the last decade. One of these requirements is in connection with the harmonic distortion of the voltage. [5] The voltage distortion is caused by the non-linear loads connected to the network on different voltage levels. The non-linear loads act as virtual harmonic current generators. Utility companies can refuse consumers to be connected to the network injecting high current harmonics. In these cases consumers are interested in installing harmonic filters to reduce the distortion; they are causing.

\section{Harmonic filtering}

Although this paper does not have any kind of filter models, it must be indicated that the final goal of the research is studying the possibilities of elimination of the harmonic distortion originating from the railway networks. That is why the method of harmonic filtering is mentioned briefly below.

\section{A. The phenomena of filtering}

Harmonic filters are used to limit the harmonic currents flowing into the upstream network and to decrease the resonance effect causing current amplification along the $25 \mathrm{kV}$ supply line. The filter could be located on the loco itself or on the substation. Because of the different type of locos running simultaneously on the same traction section the most effective place for the harmonic filter location is the $25 \mathrm{kV}$ side of the substation. Basically there are two kinds of filters: passive and active filters.

\section{B. Passive filtering}

The passive harmonic filter is simply a series resonance circuit tuned to the filtered frequency (Fig. 1). The passive harmonic filter has low impedance on its tuned frequency that is why it shunts the network for the harmonic current of the tuned harmonic order.

Harmonic filtering is often linked with the problem of fundamental frequency reactive power balance. The passive filters could be used to compensate reactive power, because they are

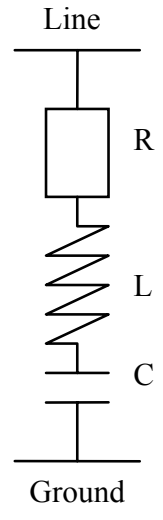

Fig. 1. Passive filter 
capacitance reactors on the base frequency.

\section{Active filtering}

The active harmonic filtering is the electronic sinusoidation of the consumer's current waveform. The active filters are controlled current generators controlled by microprocessors or microcontrollers, which inject the reciprocal value of the distortion to the network. By this procedure, the resultant pure sinusoidal shape could guarantee for the feeding current.

The active filters can also be tuned to an exact frequency. The tuned frequency component of the load current is measured and injected as anti-phase value to the network by the logic of the microprocessor. Newer generation of active filters can be used to ensure the reactive power balance.

\section{Elements of the traction supply system}

The electric railway system is consisting of four main components (Fig. 2.a). [1]

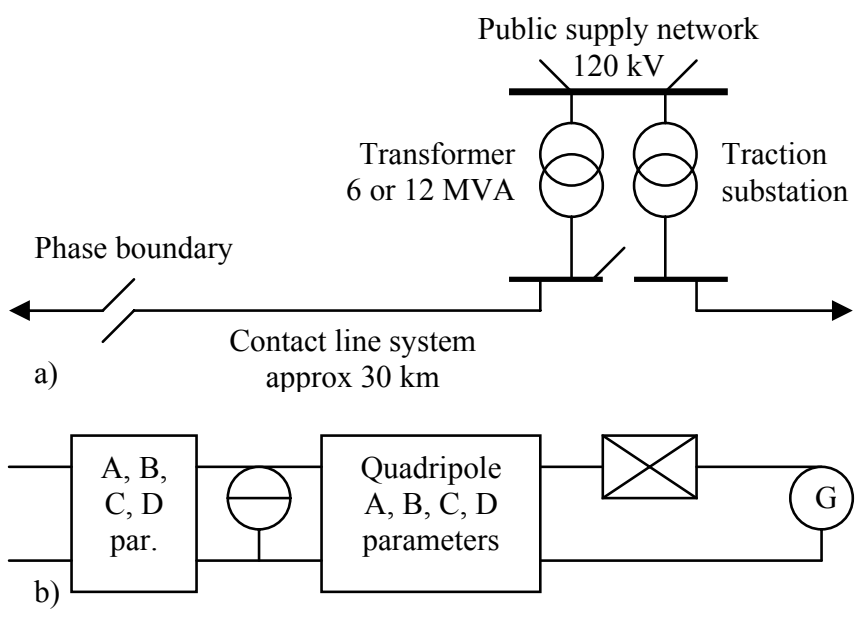

Fig. 2. Simplified circuit for calculation of harmonic effect a) general traction-current feeding arrangement b) circuit representation of contact line system

\section{A. Locomotives}

The locomotives are running under the contact line system, dividing it into two parts. At the contact point the locos could be represented by a base frequency consumer and harmonic generator. After studying the modelled engines (look at in Chapter 4.B) the following conclusions can be drawn [1]:

- In case of odd harmonics, the harmonic components significantly decreases if the order increases.

- Even harmonics are significantly smaller than the neighbouring odd harmonics.

- From the site measurements of [1] it may be concluded that the magnitude of the current harmonics injected by the locomotives is practically independent of the network configuration of the traction system and the location of the engine.

Thus the locomotive can be considered as a current generator with the odd harmonics. This statement is not valid for locomotives equipped with neither harmonic filters nor capacitor banks, but the modelled V43 and V63 type locos have neither of them.

\section{B. Contact line system}

The contact line system should be considered as a multiconductor system with earth return that is composed of the contact wire(s), suspension wire(s), and the return rails. The length of the system is an average of $30 \mathrm{kms}$, where the feeding transformer is contacted to one of the ends. The phase boundary is at the other end that separates this traction from the next traction.

The contact line system can be reduced to a two-wiresystem that leads the current. The reduction has to be performed on every harmonic. The contact line system can be considered as a quadripole (occasionally divided into two parts by the locomotive) that is terminated by the driving point impedance at the substation when the far end is open. [1]

The parameters could be used by laboratory and site measurements of the authors of reference [1].

\section{Feeding transformer}

The feeding transformer could also be considered as a quadripole which consists of the magnetizing and the leakage reactance. The establishment of the reference [1] shows that the magnetizing impedance can be neglected, so it is enough to calculate every frequency with the leakage impedance. The parameters could be calculated by an expression stated by reference [1].

Usually, there are two transformers in a substation and each of them feeds geographically two different directions. Because the two transformers contact to separate bus-bars or the bus-bar is open between the two transformers' contact point, the two tractions can be treated independently. Only if one of the transformers is under renovation or under replacing are the tractions connected, and it is not a common use. Thatswhy we do not calculate with these cases in the model, although it would not mean theoretical difference.

\section{High voltage supply network}

The driving point impedance used for the system identification is equal to the sum of the positive and negative sequence impedances of the high voltage supply network. For identification it is necessary to measure the driving point impedance in every substation which would like to be used in the model. The impedance function that are determined by the measured impedances could be used with a kind of approximate method. [1] 


\section{Models}

The following models are applied for the calculations:

\section{A. The model of traction supply system}

With the elements introduced in Chapter 3.B-D can the traction supply system be modelled, as it is shown in Fig. 2.b. This model is calculated in the frequency domain, because all the necessary parameters are given in the frequency domain.

For studying low frequency disturbance, the harmonic orders must be examined till the $50^{\text {th }}$ harmonic [5]. After the conclusion of Chapter 3.A it is enough to calculate the odd orders, so the model examines the odd harmonics from the $3^{\text {rd }}$ to $49^{\text {th }}$.

\section{B. The model of locomotives}

To calculate the sophisticated model of the electric locomotive as a non-linear load a time dependent model must be used. It determines the current spectrum of the engine in function of the distorted supply voltage. Because the voltage distortion is caused by the loco itself, an iteration algorithm was developed to convert the variables between the time and frequency domain vice and verse.

The block diagram of the locomotive could be seen on Fig. 3.a. Most of the Hungarian locos have DC traction motors. The easiest way to model it by a static representation consisting it's main field inductance, armature and commutating pole resistance and emf. Regarding the rectifier bridge it is represented with the series loss of the diodes/thyristors, and the parallel RC elements. To smooth the direct current a series reactor is connected between the rectifier bridge and the motor. This reactor together with its resistance is also considered in the calculation.

The computer model of the locomotive could be seen on Fig. 3.b. The feeding generator consists of not onlz the fundamental, but the harmonic voltages as well.

In the present paper two types of locos are investigated:

1) V43. The V43 type is the biggest scale (75\% of electric loco's) used electric engine in Hungary. (Both the Hungarian Railways Co. and the GyörSopron-Ebenfurt Railways Co. has got V43 locomotives.) This is an universal loco with $2220 \mathrm{~kW}$ power and $130 \mathrm{~km} / \mathrm{h}$ maximal speed. [9]

A special transformer with two coil systems has been installed into the engine room. The rectifier units are supplied from the secondary grindings. (The output voltage is variable from 0 to 1400 V.) The two rectifier units are feeding the two traction motors through a series reactor. The rectifier units are single phase double-way diode

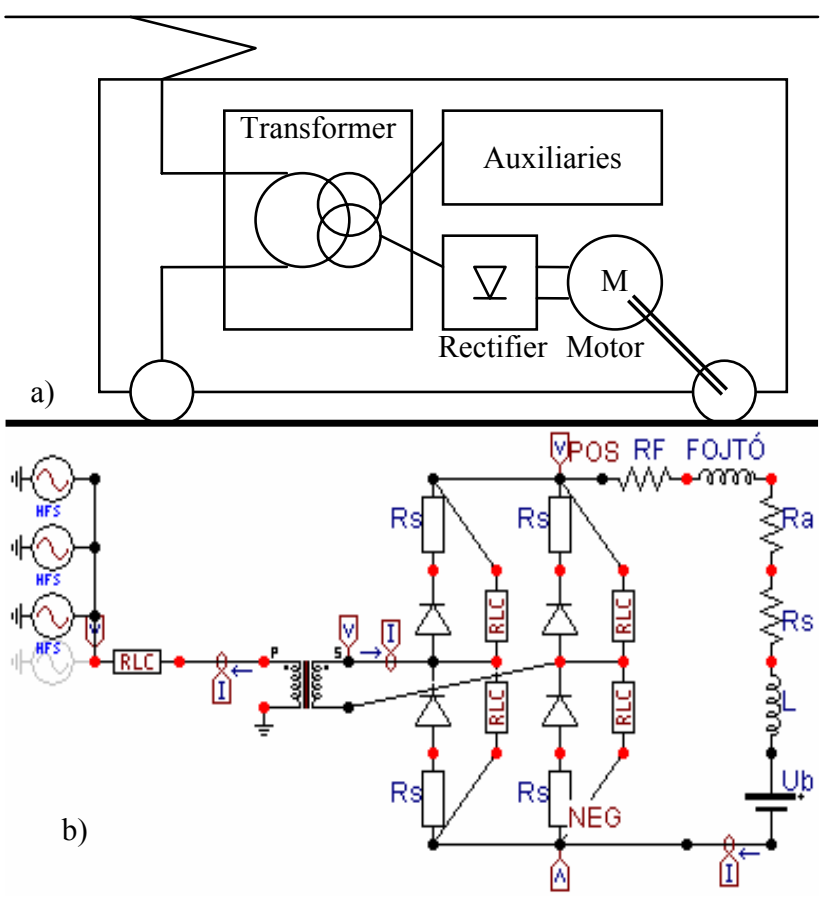

Fig. 3. Simplified locomotive model

a) block diagram, b) circuit representation in ATP-EMTP

bridges. The simplified circuit (with one traction motor) is presented on Fig. 3. [2], [6], [7]

2) V63. The V63 type locomotives (11 \%, 56 pieces) are specialised for heavy freight trains and fast passenger trains with $3600 \mathrm{~kW}$ power and $120-160 \mathrm{~km} / \mathrm{h}$ maximal speed. [9]

This locomotive has got six DC motors (for each axles) are feeding through a series reactor by two-two series connected semi controlled rectifier bridge. The secondary voltage of the engine transformer coils are $568 \mathrm{~V}$, the voltage level of DC motors could be controlled by the firing angle of the thyristors. [8]

\section{How to run the model?}

Initially a sinusoidal voltage is feeding the locomotive. The traction system of the locomotive is modelled with different indication. The spectral components of the calculated current time function are injected into the network. In this case the network is modelled in frequency domain. Te resultant distorted voltage is used in the next step as a time function supplying the locomotive. This procedure is followed like an iteration calculation until the difference of the calculated harmonic voltages of any order of two consecutive steps gets low enough. The test calculations with one or two locomotives and $1 \%$ tolerance needed no more than 8 iterations.

\section{Results}

There are some key points to build up below which are characteristic regarding the railway systems:

\section{A. Current amplification along the $25 \mathrm{kV}$ supply line}




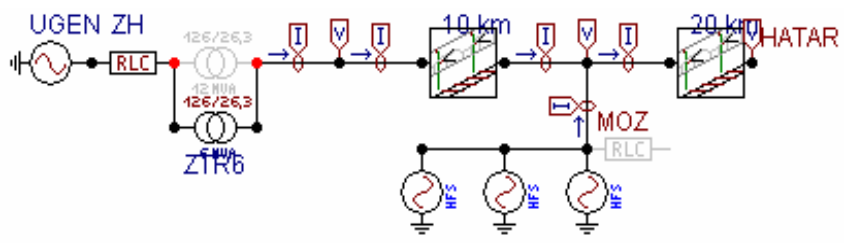

Fig. 4. The traction supply system model

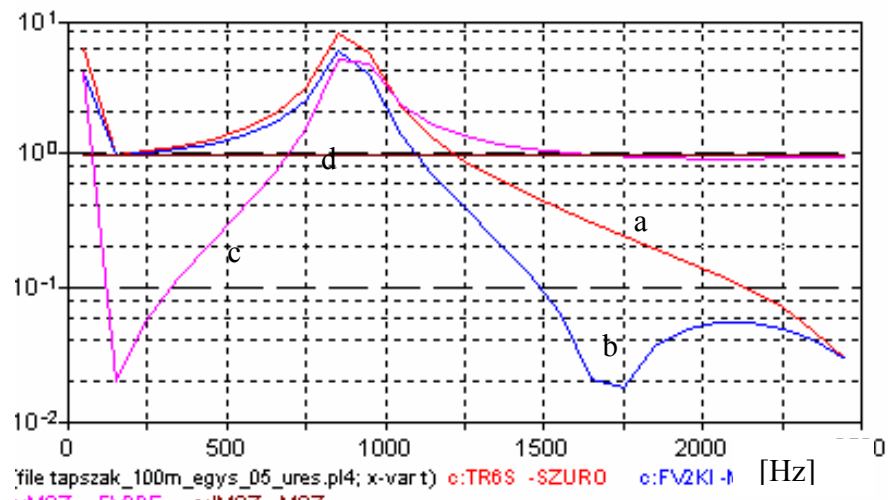

Fig. 5. Current amplification. Currents at the substation (a), at the locomotive to substation (b), to phase boundary (c), injected current spectrum (d)

Harmonics are causing resonance effect along both the $25 \mathrm{kV}$ supply line and the upstream network. The current amplification could be studied directly if the locomotive is replaced by a current generator injecting unitary current on every examined order.

ATP-EMTP was used for the time domain and frequency domain simulation. The simulation model of traction system in the ATP-EMTP is given on Fig. 4, the calculated current amplification along the $25 \mathrm{kV}$ supply line could be studied on Fig. 5 (the locomotive (unitary current generator) is $10 \mathrm{~km}$ from the substation).

The result shows, that the amplification is the highest at the $17^{\text {th }}$ harmonic order, because of the parallel resonance circuit composed by the inductance of the substation (transformer and upstream network) and the capacitance of the $25 \mathrm{kV}$ supply line. A 'natural filter' could be seen on Fig. 5. at the $33^{\text {rd }}-35^{\text {th }}$ harmonic order where the amplification level is the lowest.

\section{B. Calculating with V43 locomotive}

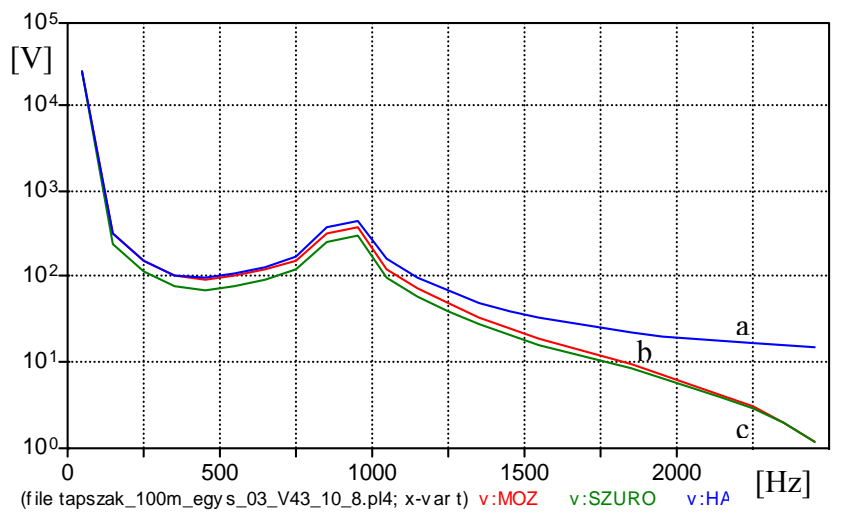

Fig. 8. Voltages with V43 loco, a: on the loco, b: at the substation, c: by the section border

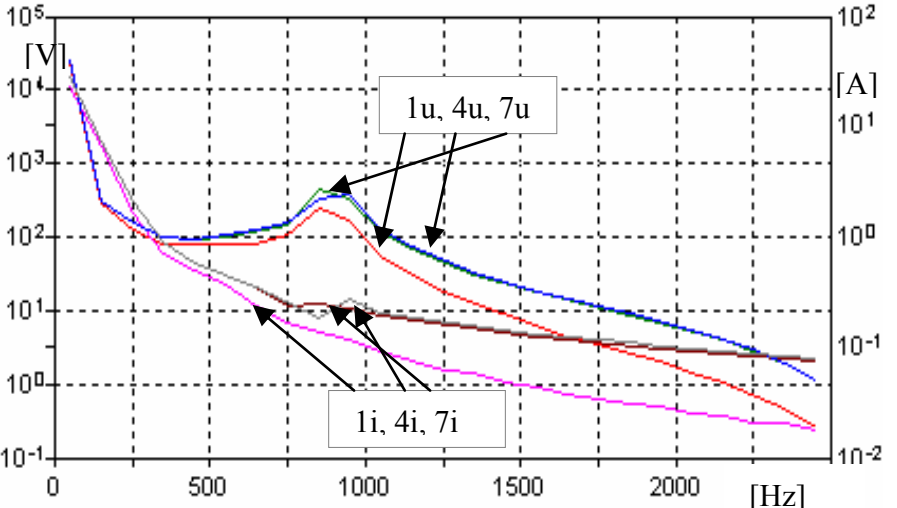

tapszak $100 \mathrm{~m}$ equs 03 v43 10 2.ol4: v:MOZ c:llMOZ -MOZ

t Fig. 6. Iteration, 1u, 4u, 7u: loco voltage spectrum, 1i, 4i, 7i: $\mathrm{t} \quad$ loco current spectrum after the $1^{\text {st }}, 4^{\text {th }}$ and $7^{\text {th }}$ step

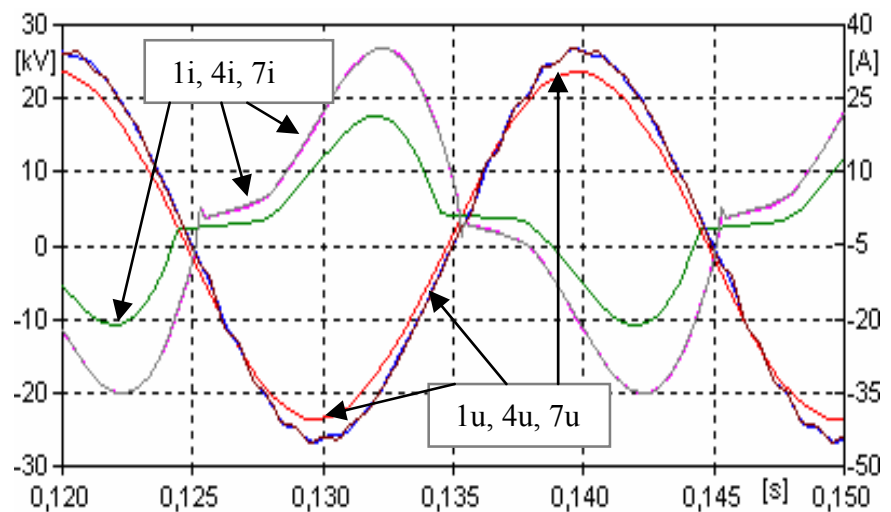

43_2motoros kis2 10km 01.ol4: v:CSATL c:TRP -CSATL1

443. Fig. 7. Iteration, $1 \mathrm{u}, 4 \mathrm{u}, 7 \mathrm{u}$ : loco voltage shape, 1i, 4i, 7i:

43. loco current shape after the $1^{\text {st }}, 4^{\text {th }}$ and $7^{\text {th }}$ step

The calculation needed 7 steps. The variation of locomotive current and voltage spectrum and shape could be seen on Fig. 6 and 7. The difference between the $4^{\text {th }}$ and $7^{\text {th }}$ step is not notable, because the base frequency component has not varied after the $3^{\text {rd }}$ step and the biggest part of harmonic orders had only $1-2 \%$ variation. But the higher amplifier $17^{\text {th }}$ and $19^{\text {th }}$ order had more difference, that is why more steps were needed.

Fig. 8 and 9 show the calculated voltage and current spectrum along the supply line.

\section{Calculating with V63 locomotive}

After the V43 loco has been replaced by the V63 model with $5^{\circ}$ and $30^{\circ}$ firing angle for the thyristors of the two

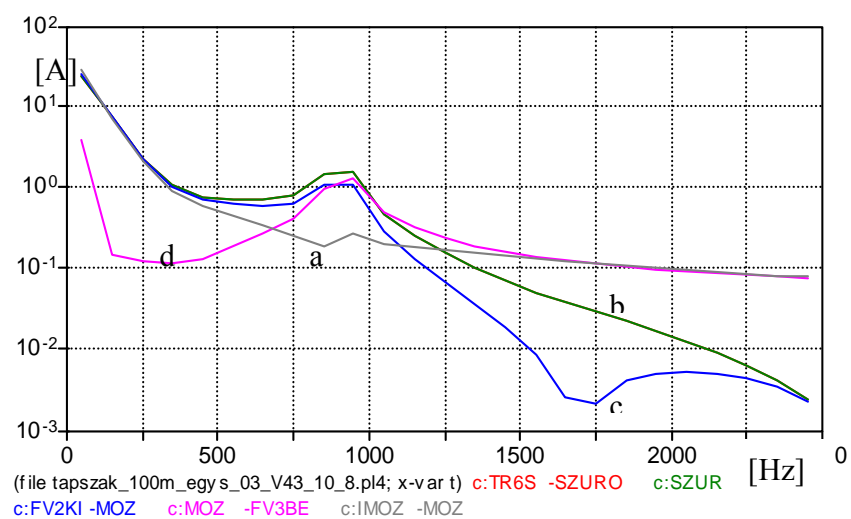

Fig. 9. Currents with V43 loco, a: injected by the loco, b: at the substation, c: at the loco to the substation, d: to the section border 


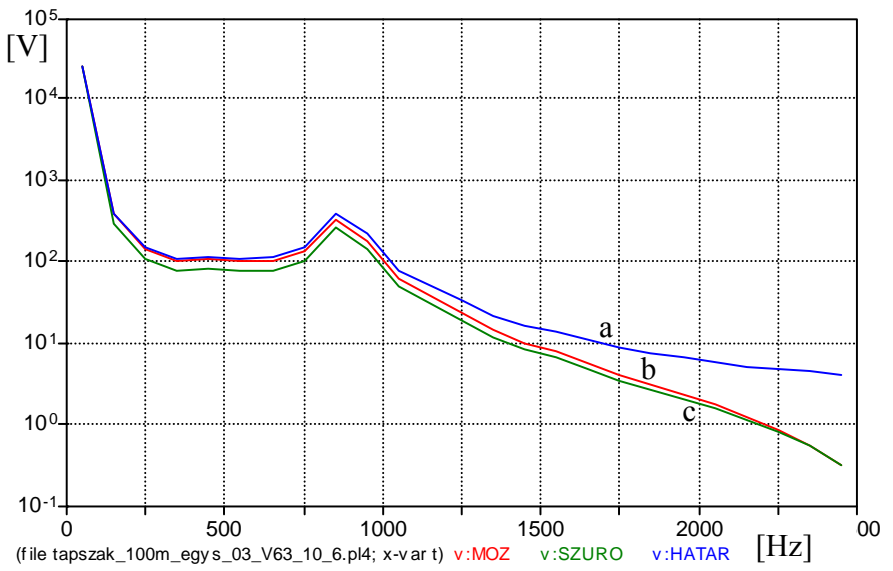

Fig. 10. Voltages with V63 loco, a: ont he loco, b: at the substation, c: by the section border

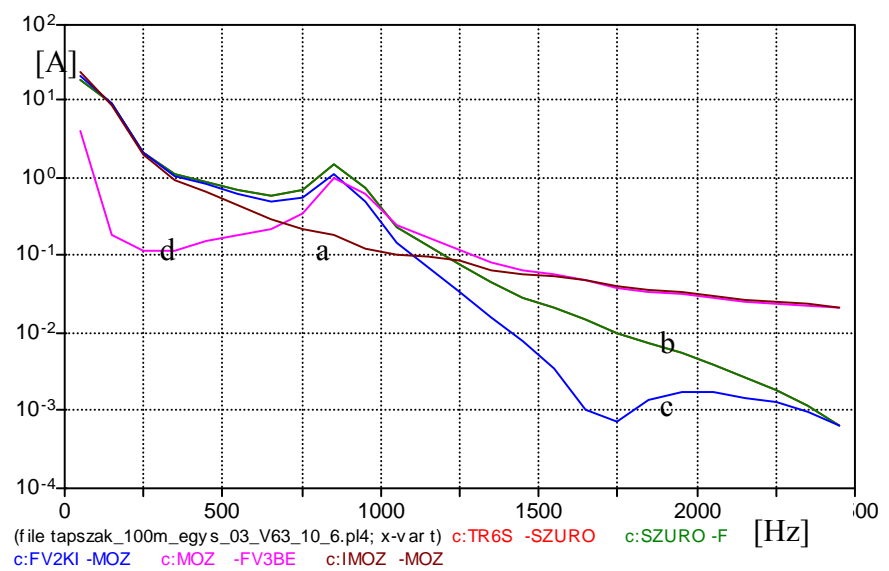

Fig. 11. Currents with V63 loco, a: injected by the loco, b: at the substation, c: at the loco to the substation, $\mathrm{d}$ : to the section border series connected semiconducting rectifier bridge, the calculates need 6 steps. The results can be seen on Fig. 10 and 11.

Both V43 and V63 calculation results are agreeable to the results of site measurements by the same traction supply system and upstream network configuration.

\section{Future development possibilities}

This work is the $\mathrm{PhD}$ thesis of the student author (Péter Kiss) who is modelling the other types of locomotives running on the Hungarian railway lines.

\section{A. Other locomotives}

There are two more type of locos used by the Hungarian Railways Co. and Györ-Sopron-Ebenfurt Co. The V46 type engine (12\%, rated power: $820 \mathrm{~kW}$, max. speed: 80 $\mathrm{km} / \mathrm{h}$ ) is a shunt locomotive, and represent the up-to date technology among the locomotives supported by DC motors. [9] The 1047 type locomotives (3\%, rated power: $6400 \mathrm{~kW}$, max. speed: $200 \mathrm{~km} / \mathrm{h}$ ) are the newest ones in Hungary, it has got asynchronous AC motors with IGBT rectifier and inverter bridges. It must be marked that this kind of locomotives could be not modelled as a conventional harmonic current generator, because the ac side rectifier is basically a voltage source type and the engine can run with arbitrary power factor and the statement of Chapter 3.A [10] is not valid in this case.

After the present modelled locomotives it must be studied the so called electrical multiple units (3 types, alltogether 25 vehicles, rated power: $1420-1755 \mathrm{~kW}$, max speed: 120 $\mathrm{km} / \mathrm{h}$ ), and should not forget the locos are running into Hungary from the neighbour countries, too. [9]

After all kind of engines have been modelled, wide scale of locomotive and traction system configuration can be studied regarding their harmonic disturbance.

\section{B. Harmonic elimination}

The passive filters could be modelled and added to the model of traction supply system (in frequency domain) easily as frequency dependent shunt impedance at the substation.

The active filters are controlled current generators controlled by microprocessors or microcontrollers, and could be modelled advantageously in the time domain. Our goal is to make the model of active harmonic filtering with a kind of iteration developed by the locomotive model.

\section{Conclusion}

The importance of this paper indicates that its topic is in connection with one of the priorities of the Hungarian State Railways. This is the project of planning compensation and harmonic filtering to the railway substations to reduce the distortion, resulting in decrease of losses, it means energy saving.

The results of the presented simulation - using the double domain (frequency and time) iteration method and the locomotive models in the time domain - are agreeable to show very good coincidence with the site measurements, and the iteration calculates near to the real harmonic disturbance along the $25 \mathrm{kV}$ supply lines including the substation and the far end as well.

Future plans are the modelling of all possible railway substation configuration, taking into account the different locos. The double domain simulation method will help to select the most advantageous solution, regarding the composition of reactive power compensation, active and passive filtering.

\section{Acknowledgement}

The authors acknowledge the continuous support of Hungarian State Railways Co. (MÁV) during this project.

\section{References}

[1.] A. Dán, J. Kisvölcsey, Gy. Varjú, "Filtering of harmonics generated by thyristor controlled AC traction systems", in Proc. II. International Conference on 
Harmonics in Power Systems, pp. 404-413, Winnipeg, 6-7. October, 1986

[2.] Gy. Retter, "Electrical converter devices" (Villamosenergia átalakítók), Budapest: Müszaki Könyvkiadó, Budapest (1986), Vol. 1

[3.] M.M.M. L. Arini, "Time domain load modelling technique and harmonic analysis", in Proc. 8th. International Conference on Harmonics and Quality of Power pp. 930-939, Athens, 14-16. October, 1998.

[4.] P. Brogan, R. Yacamini, "Measurements and simulation of an active filter based on voltage feedback", in Proc. 8th. International Conference on Harmonics and Quality of Power pp. 930-939, Athens, 14-16. October, 1998.

[5.] A. Dán, "The Quality of the Energy with Enlarged Diameter of Copper Wires" (A villamosenergia-minőség növelt rézkeresztmetszettel), Hungarian Copper Promotion Centre (Magyar Rézpiaci Központ), Budapest (1999)

[6.] V. Horváth, Z. Zádori ed., "The Technical Introduction and Instructions for Use for Engine-Drivers" (Villamos mozdonyok müszaki leírása és kezelési utasítása a mozdonyvezetők részére), Közdok, Budapest (1983)

[7.] "The Technical Introduction of the Electrical Elements in V43 type Locomotives" (A V43. sor. mozdony villamos berendezésének müszaki leírása, kezelési és karbantartási utasítása), Ganz Electricity Works (Ganz Villamossági Müvek), Budapest (1971)

[8.] I. Mezei ed., "The Construction, Operation and Handling of V63 type Locomotives" (A V63 sorozatú mpzdpny szerkezete, müködése és kezelése), Hungarian State Railways Co, Budapest (1998) [9.] Gigant Club

homepage,

[10.] I. Elöhegyi, "Electric locomotives supported by asynchronous motors" (Aszinkron motoros villamosmozdonyok), Hungarian State Railways Co. and Györ-Sopron-Ebenfurt Railways Co., Budapest and Sopron (2002) 